\title{
Collocational competence of primary and secondary school students
}

\author{
Evelina Miščin \\ University of Applied Sciences 'Baltazar' Zaprešić
}

\begin{abstract}
The aim of the paper is to test collocational competence of primary and secondary school students to establish the most frequent problems they encounter. Based on these collocational errors teachers could devise their teaching material and help students in improving their collocational competence.
\end{abstract}

Key words: collocations; collocational errors; collocational competence; productive knowledge; receptive knowledge.

\section{Introduction}

This paper wants to investigate collocational competence of primary and secondary students in order to see what the most frequent problems they encounter are and to help later in their collocational competence at the university level. If teachers are familiar with the most common collocational errors, it could help them to devise their teaching material thus enhancing their students' collocational competence.

The paper will start with a short theory of collocations, and then proceed with the explanation of the research mentioning subjects, instrument and methods. In the end, the results will be analysed and the conclusion will be made.

\section{Theoretical Framework}

Collocations are combinations of words on syntagmatic level, first described by Firth (1957), who mentions that "you know a word by the company it keeps". According to him, the relation between lexical units can be shown by two axis, a ver- 
tical one which is paradigmatic and includes words of the same class and the horizontal one, which is syntagmatic and refers to the ability of words to connect one with another. In a sentence, for example, Sara plays the flute, flute is in a paradigmatic relation to piano, cello and in syntagmatic relation with plays and Sara. Crystal (1995) mentions that lexical items involved in collocations are always, to some degree, mutually predictable. Morton et al. (1986) distinguished between grammatical and lexical collocations. Grammatical collocations are those that include prepositions, infinitives or sentences while lexical collocations include nouns, adjectives, verbs and prepositions.

McCarthy (1995) thinks that the relationship of items in a collocation is fundamental to the study of vocabulary and it is a part of the native speakers' competence. Some other theoreticians also recognised the importance of collocations particularly due to the interference with mother tongue. Thus, in 1999, Hill introduced the term 'collocational competence' used also previously by Nattinger and DeCarrico (1992).

McCreton and Rider (in James, 1998) pointed out the importance of mistakes made by non-native speakers of English and illustrated it in the following way:

THE MOST SERIOUS

THE LEAST SERIOUS

Lexis $>$ spelling $>$ negation $>$ word order $>$ prepositions $>$ verb forms $>$ concord

Figure 1. Hierarchy of mistakes according to McCretton and Rider (James 1998: 229)

Collocational mistakes belong to lexical ones and as it can be seen in Figure 1, they are the most serious mistakes which can lead to misunderstanding. Several researchers propose raising awareness of collocations by pointing out to students their mistakes (Woolard, 2000). Lewis (2000) also emphasised that students should also be aware of wrong combinations, not just the correct ones. Miščin (2012) tested 297 first year medical students. The target of the research were verb-noun medical collocations which were tested by multiple choice, gap-fill and translations both from English to Croatian and vice versa. The results showed that receptive tasks were much easier for the participants than the productive ones. Pavičić \& Miščin (2013) conducted a similar study where they tested 50 first year medical students, 51 fifth year medical students and 26 doctors. The test consisted of receptive and productive tasks (multiple choice, gap-fill and translations both from Croatian into English and vice versa). The results showed that the collocational competence was similar in all three groups and that their receptive knowledge was much better than the productive one. Miščin (2015) tested 20 first year and 20 second year business English students. This time verb-noun and adjective-noun 
business collocations were tested by multiple choice and gap fill. The results showed that the receptive knowledge was much better than the productive one and that students were more competent in verb-noun collocations than adjectivenoun collocations. Table 1 gives the list of some of the studies on the acquisition of collocations.

Table 1 shows that most students make collocational mistakes. With language proficiency, these mistakes decrease. It also indicates that the receptive knowledge is much better than the productive one, in general English, medical and business English.

\section{Materials and method}

The study wanted to test collocations which appear in the obligatory textbooks. Only collocations from textbooks were used, not from workbooks, presuming that not all children had workbooks. The following textbooks were used for primary school: Project, Building Bridges, Way to Go. Only textbooks for classes from $5^{\text {th }}$ to $8^{\text {th }}$ were analysed. The following textbooks were used for secondary school: New Matrix, Solutions, English in Mind, Tune up, Log on @, New Opportunities, Success. The exercises with collocations were looked for, while the texts were not analysed. Sometimes, collocations were referred to as word partnerships or word combinations. After that, the test was devised which included the most frequent collocations and its purpose was to test collocational competence of students to see if it was enough to expose students to collocations in exercises. The following research questions were posed:

1) Which are the most frequent types of collocations used in English textbooks?

2) What is the level of collocational competence of primary and secondary school students of English?

3) Is there any difference in collocational competence between different primary/secondary schools?

\subsection{Analysis of collocations in primary school textbooks}

Collocations in textbooks were analysed in the exercises that appear either before or after the text. Collocations in the texts were not analysed and included in the survey. Table 2 shows types of exercises in which collocations were used and how many times. 


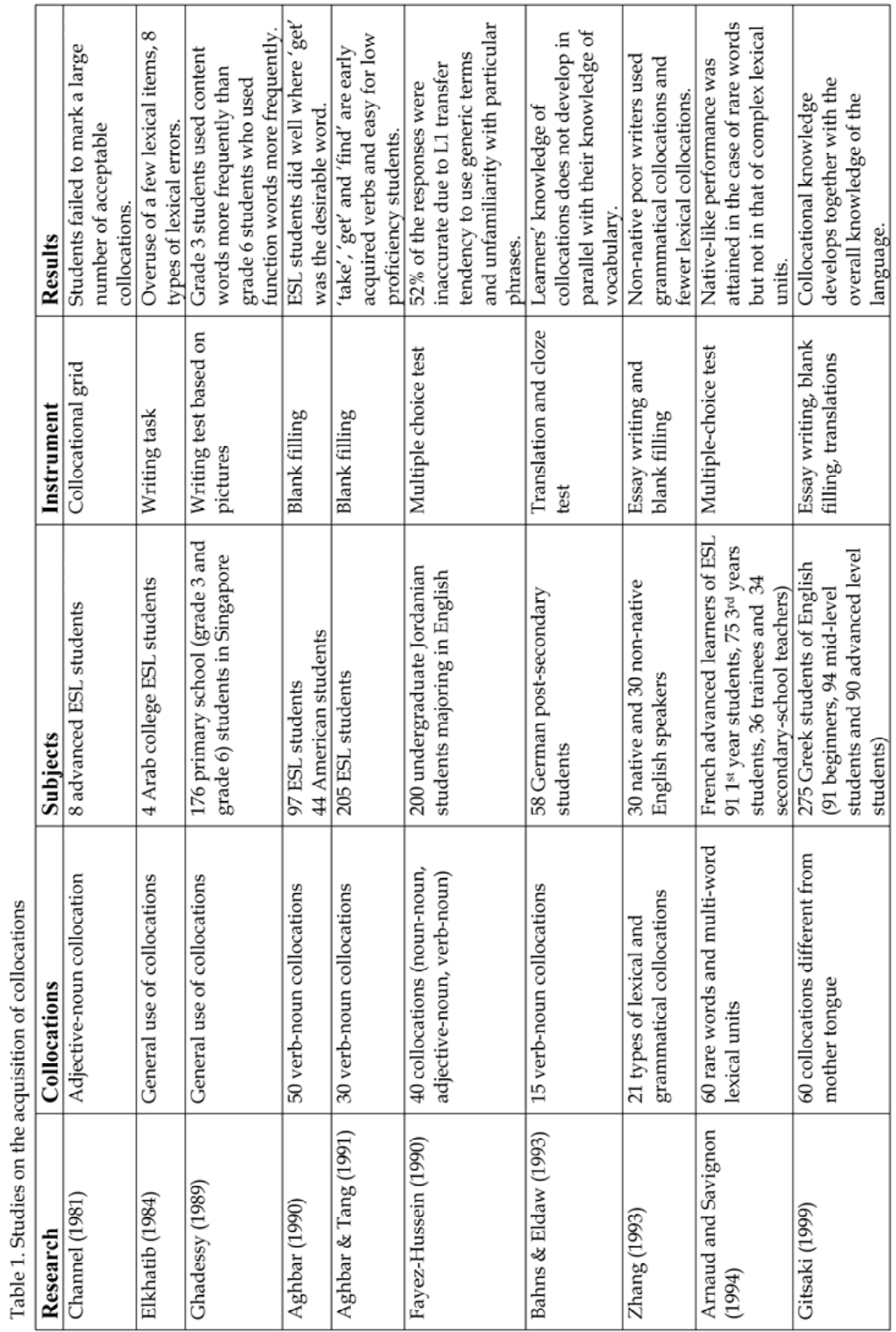




\begin{tabular}{|c|c|c|c|c|c|}
\hline 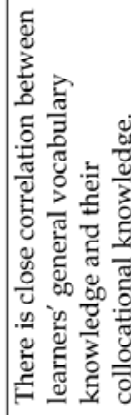 & 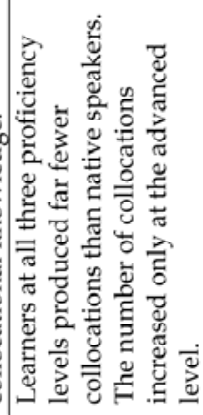 & 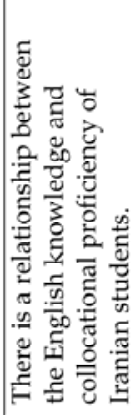 & 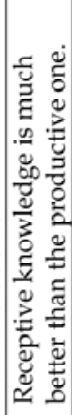 & 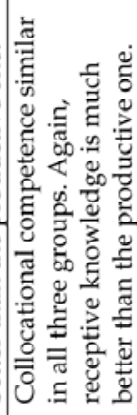 & 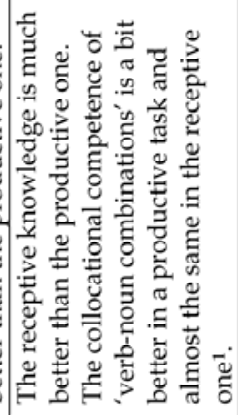 \\
\hline 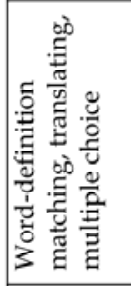 & 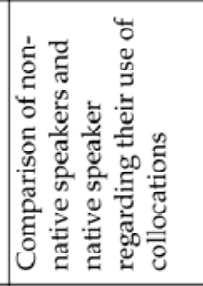 & 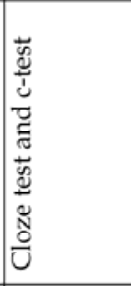 & 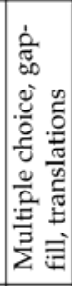 & 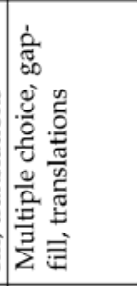 & 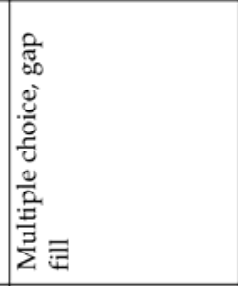 \\
\hline 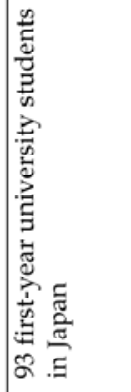 & 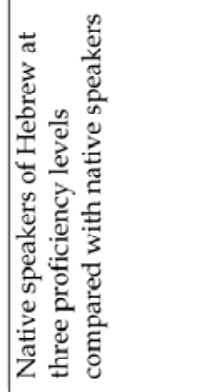 & 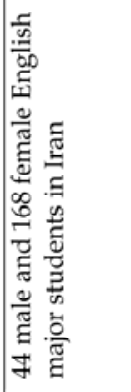 & 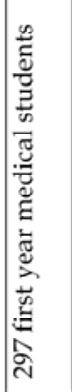 & 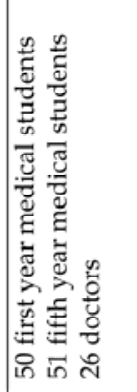 & 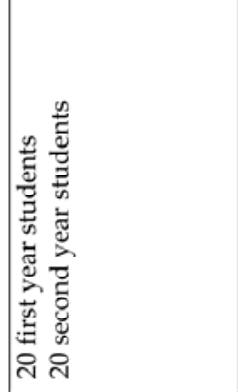 \\
\hline 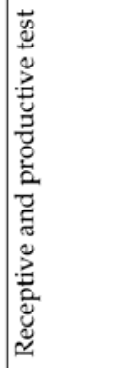 & 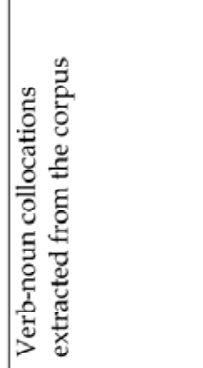 & 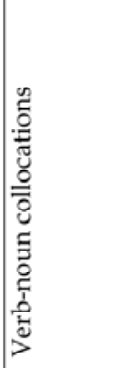 & 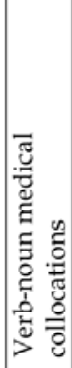 & 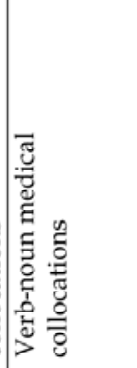 & 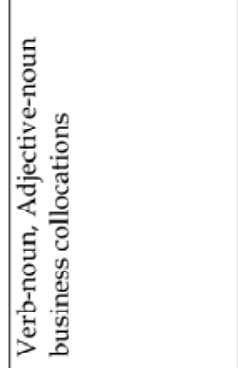 \\
\hline 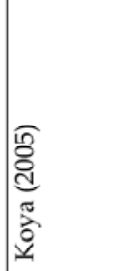 & 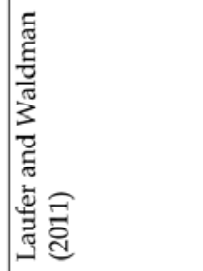 & 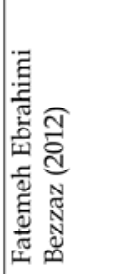 & 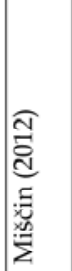 & 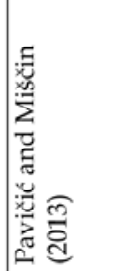 & 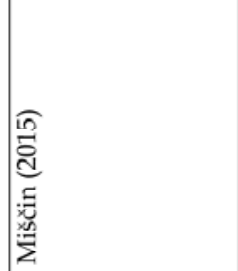 \\
\hline
\end{tabular}

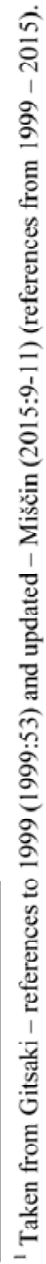


Table 2. Types of exercises in primary school textbooks.

\begin{tabular}{|c|c|}
\hline Type of exercises & Number of occurrences \\
\hline Answering questions & 1 \\
\hline Filling the table (while listening) & 1 \\
\hline Writing sentences by using collocations & 2 \\
\hline Matching pictures with collocations & 1 \\
\hline Speaking about yourself or another person & 2 \\
\hline A dialogue with collocations & 1 \\
\hline Matching exercises & 9 \\
\hline $\begin{array}{l}\text { Completing a chart by making a collocation } \\
\text { from the verb }\end{array}$ & 1 \\
\hline Filling in sentences & 2 \\
\hline Sorting into categories & 1 \\
\hline Completing sentences with the correct verb & 2 \\
\hline Glossary & 1 \\
\hline Yes/no sentences & 1 \\
\hline Answering questions with collocations & 1 \\
\hline Asking and answering questions & 2 \\
\hline Listening and ticking correct answers & 2 \\
\hline Translating & 7 \\
\hline Filling the table with 3 verbs & 1 \\
\hline Finding collocations in the text & 1 \\
\hline
\end{tabular}

As can be seen from Table 2, the exercises in all textbooks are quite scarce. The highest number of exercises are matching exercises followed by translations. Most of the exercises are receptive and only a few are productive. The most frequent collocations are upward collocations, i.e. those in which the first element is a collocate and the second one a node (e.g. 'do homework' where 'do' is a collocate and 'homework' a node). 


\subsection{Analysis of collocations in secondary school textbooks}

The situation in secondary school books is quite similar. Table 3 shows types of exercises which are the most common.

Table 3. Types of exercises in secondary school textbooks.

\begin{tabular}{|l|c|}
\hline \multicolumn{1}{|c|}{ Type of exercises } & $\begin{array}{c}\text { Number of } \\
\text { occurrences }\end{array}$ \\
\hline Matching exercises (parts of collocations) & 19 \\
\hline Gap fill & 1 \\
\hline Completing the sentences & 7 \\
\hline Providing a verb/a noun & 4 \\
\hline Classifying into categories (V+N, Adj+N, V+Adj, V+Adv) & 1 \\
\hline Classifying into categories - nouns with make/do, take/put & 2 \\
\hline Glossary & 3 \\
\hline $\begin{array}{l}\text { Guessing the noun which collocates with certain verbs or adjec- } \\
\text { tives }\end{array}$ & 2 \\
\hline Completing the vocabulary network & 1 \\
\hline Writing sentences with collocations & 2 \\
\hline Matching collocations and their meaning & 1 \\
\hline Using a dictionary entry and completing the sentence & 1 \\
\hline Filling in the table & 1 \\
\hline Mind map & 1 \\
\hline
\end{tabular}

As it can be seen in Tables 2 and 3, there are a bit more exercises with collocations in secondary school textbooks. It might be the result of considering those children more competent for the use of more complicated tasks. Again, the most frequent collocations are upward collocations, especially combinations verb + noun, verb + adjective, verb + adverb, adjective + noun.

\subsection{Participants}

The research was carried out at two different primary schools and two different secondary schools. It included 40 primary and 40 secondary school children, 20 from each school. Each category included one small town school and one big town school in order to show if children from bigger towns were better as they also had more opportunities for studying English outside school. Participants from primary schools were 8th grade students and from secondary school 3rd grade students as the test was taken in June when 4th grade students were already preparing for their final exams. Out of 20 bigger city primary school children, 6 learn English out of school and 6 did not provide the answer so it can just be presumed that they do 
not learn English out of school. Out of 20 smaller city primary school children 6 learn out of school and the remaining 14 do not. Regarding sex distribution, 7 boys and 13 girls participated from the bigger city primary school and 8 boys and 12 girls from the smaller city primary school, so the numbers are quite similar.

Out of 20 bigger city secondary school children 4 learn English out of school, 15 do not and 1 did not provide the answer. Out of 20 smaller city secondary school children 1 learns English out of school, 16 do not and 3 did not provide the answer. Regarding sex distribution, 10 boys and 10 girls took part from a bigger city secondary school and 9 boys and 11 girls from a smaller city secondary school.

\subsection{Instrument}

The instrument used for the research was a collocational competence test. It consisted of four groups of exercises - a multiple choice, a gap-fill, a translation from English into Croatian and a translation from Croatian into English. Therefore, the first exercise tested a receptive level of collocational knowledge (a multiple choice), the second and the fourth tested a productive level (gap-fill and translation from Croatian into English). The third group belonged to a productive level as the students had to recognise the meaning of the collocation in English and give its translation. Each group had 5 sentences which gives the total of 20 questions.

\subsection{Procedure}

Students were tested during their regular English class. The instructions were given in English and they had 20 minutes to do the test. The test was done anonymously.

\subsection{Scoring criteria}

The maximum score result for each exercise was 5 points, so the total was 20 points. Each correct answer was awarded one point. All correct answers were taken into account, not only those that could be found in the textbooks, but also in collocation dictionaries (BBI, Oxford). In translations, only underlined collocations were taken into account and it was not important if other parts of sentences were correct. The aim of the test was only to check the scope and level of collocational knowledge. 


\section{Results and discussion}

\subsection{Primary school results}

The most frequent errors of the tests can be seen in tables 4, 5, 6 and 7. A target collocation was given in the first column, while the other two show the most frequent errors of bigger city students and smaller city students. Table 3 shows the most frequent errors of the multiple choice task.

Table 4. The most frequent errors of the multiple choice task.

\begin{tabular}{|l|l|l|}
\hline \multirow{2}{*}{ Target collocation } & \multicolumn{2}{|c|}{ The most frequent errors } \\
\cline { 2 - 3 } & Bigger city students & Smaller city students \\
\hline go cycling & ---- & do cycling \\
\hline play tennis & ----- & ----- \\
\hline do gymnastics & go gymnastics & play gymnastics \\
\hline play football & ----- & ----- \\
\hline go swimming & ------ & do swimming \\
\hline
\end{tabular}

As can be seen from Table 4, students made only a few errors, which was expected as they could choose among three answers. The most difficult collocation here was 'do gymnastics'. Table 5 shows the most frequent errors of a gap-fill exercise which proved to be more difficult.

Table 5. The most frequent errors of the gap-fill task.

\begin{tabular}{|l|l|l|}
\hline \multirow{2}{*}{ Target collocation } & \multicolumn{2}{c|}{ The most frequent errors } \\
\cline { 2 - 3 } & \multicolumn{1}{|c|}{ Bigger city students } & Smaller city students \\
\hline Keep a secret & Hide a secret & $\begin{array}{l}\text { Tell a secret, know a secret, } \\
\text { find out a secret }\end{array}$ \\
\hline Do the vacuuming & Finish the vacuuming & Finish the vacuuming \\
\hline Do/write homework & Finish homework & $\begin{array}{l}\text { Make homework/ have } \\
\text { homework }\end{array}$ \\
\hline Make a noise & Do a noise, such a noise & Too a noise \\
\hline Tidy/ clean the room & -------- & $\begin{array}{l}\text { Make the room / tied the } \\
\text { room }\end{array}$ \\
\hline
\end{tabular}

As can be seen in Table 5, the most difficult collocation for students was 'keep a secret' where most different collocational errors were made. Students used semantically wrong collocations instead of 'do the vacuuming' and 'do/write homework' with the same verb 'finish'. Some students had a problem with 'make a noise' and did not understand that the verb is missing, thus resulting in combination like 
'such a noise' and 'too a noise' where they probably mistook the noun 'noise' for the adjective 'noisy'. 'Tidy the room' is the collocation used in textbooks. However, only two bigger city students used that collocation while nobody used it in a smaller school. One student used 'tied the room' and it can be presumed that he/she had this collocation on his/her mind, but misspelled it.

Table 6 deals with mistakes in translation from English into Croatian.

Table 6. The most frequent errors of the translation from English into Croatian.

\begin{tabular}{|c|c|c|}
\hline \multirow[t]{2}{*}{ Target collocation } & \multicolumn{2}{|c|}{ The most frequent errors } \\
\hline & Bigger city students & Smaller city students \\
\hline $\begin{array}{l}\text { Prati zube (brush your } \\
\text { teeth) }\end{array}$ & Oprati zube & Oprati zube \\
\hline Ručamo (have lunch) & $\begin{array}{l}\text { Imamo ručak, moramo } \\
\text { ručati }\end{array}$ & $\begin{array}{l}\text { Imamo ručak, imamo } \\
\text { doručak, jedemo ručak }\end{array}$ \\
\hline $\begin{array}{l}\text { Obavlja kupovinu } \\
\text { (does the shopping) }\end{array}$ & $\begin{array}{l}\text { Ide u kupovinu } \\
\text { Obavlja šoping } \\
\text { Kupuje sve što je po- } \\
\text { trebno } \\
\text { Kupuje namirnice } \\
\text { Ide u šoping } \\
\text { Obavlja dućan }\end{array}$ & $\begin{array}{l}\text { Kupuje stvari } \\
\text { Ide u šoping } \\
\text { Ide u kupovinu } \\
\text { Ide u dućan } \\
\text { Kupuje } \\
\text { Sve kupuje }\end{array}$ \\
\hline $\begin{array}{l}\text { Slijediti upute (Follow } \\
\text { the instructions) }\end{array}$ & $\begin{array}{l}\text { Pratiti upute } \\
\text { Pratiti instrukcije } \\
\text { Raditi prema uputama } \\
\text { Slijediti instrukcije } \\
\text { Pisati upute } \\
\end{array}$ & $\begin{array}{l}\text { Pratiti upute } \\
\text { Slijediti instrukcije } \\
\text { Pratiti instrukcije } \\
\text { Pratiti nastavu }\end{array}$ \\
\hline $\begin{array}{l}\text { Slikali } \\
\text { smo/fotografirali smo } \\
\text { (took some photo- } \\
\text { graphs) }\end{array}$ & $\begin{array}{l}\text { Uslikali smo } \\
\text { Napravili smo fotogra- } \\
\text { fije } \\
\text { Uzeli smo par fotogra- } \\
\text { fija } \\
\text { Slikali smo nekoliko } \\
\text { slika }\end{array}$ & $\begin{array}{l}\text { Slikali smo fotografije } \\
\text { Uslikali smo par slika } \\
\text { Uzeli smo fotografije } \\
\text { Uzeli smo nekoliko slika } \\
\text { Fotografili smo nekoliko } \\
\text { puta } \\
\text { Pričali smo s fotografima }\end{array}$ \\
\hline
\end{tabular}

As can be seen from Table 6, students make collocational errors in their native language. The English collocation that had to be translated is in the first column in the brackets. Students' mistakes can be either the result of their lack of knowledge of English collocations or the lack of knowledge of its mother tongue counterpart. The first collocation in this exercise (brush your teeth) was the easiest for students though they translated it with a verb oprati which denotes a finished action but was still accepted as a correct answer. Surprising answers were obtained for the 
collocation 'have lunch' where some students literally translated it as imati ručak. 'Follow the instructions' proved to be difficult for smaller city primary school students with only 3 correct answers where they either misunderstood the collocate or the node. However, 'took some photographs' proved to be the most difficult for both groups of students where they also translated it literally (uzeli smo par fotografija, uzeli smo nekoliko slika) or completely misunderstood it, like pričali smo s fotografima where it can be presumed that the verb 'take' was mistaken for the verb 'talk'.

Table 7 shows the results of the most difficult exercise, translating from Croatian into English.

Table 7. The most frequent errors of the translation from Croatian into English.

\begin{tabular}{|c|c|c|}
\hline \multirow{2}{*}{ Target collocation } & \multicolumn{2}{|c|}{ The most frequent errors } \\
\hline & Bigger city students & Smaller city students \\
\hline Take/have shower & $\begin{array}{l}\text { Shower } \\
\text { Wash } \\
\text { Go to shower }\end{array}$ & $\begin{array}{l}\text { Shower } \\
\text { Take bath } \\
\text { Bath } \\
\text { Go to shower }\end{array}$ \\
\hline Make mistake & $\begin{array}{l}\text { Wrong } \\
\text { Get it wrong }\end{array}$ & $\begin{array}{l}\text { Be wrong } \\
\text { Do mistake } \\
\text { Miss } \\
\text { Get wrong } \\
\text { Mistake }\end{array}$ \\
\hline Lay/set the table & $\begin{array}{l}\text { Set up the table } \\
\text { Make the table } \\
\text { Put a table } \\
\text { Serve the table }\end{array}$ & $\begin{array}{l}\text { Make a table } \\
\text { Do the table } \\
\text { Do the desk }\end{array}$ \\
\hline Win the medal & Reach the medal & $\begin{array}{l}\text { Get a medal } \\
\text { Earn a medal }\end{array}$ \\
\hline Beat the opponent & $\begin{array}{l}\text { Win a competitor } \\
\text { Win the enemy } \\
\text { Beat the enemy } \\
\text { Beat the competition } \\
\text { Win the opponent } \\
\text { Beat this one }\end{array}$ & $\begin{array}{l}\text { Win the } \\
\text { Beat rivalry } \\
\text { Win the enemy } \\
\text { Concur the other player } \\
\text { Fight my enemy }\end{array}$ \\
\hline
\end{tabular}

This exercise which tested the productive level of knowledge, proved to be very difficult. The smallest number of errors occurred with 'take/have shower' but only because the American variant 'shower' where noun is used as a verb, was accepted. Nobody used 'have shower' although this collocation was used in textbooks. 'Make mistake' caused problems because students did not know the node, so they 
used the most similar word. Although 'lay the table' was used in textbooks, no student used that collocation, only its synonym 'set the table'. However, in this collocation students were less familiar with its collocate, resulting in strange combinations like 'set up the table', 'make a table', 'do the table' or 'put a table'. The most difficult in this exercise was 'beat the opponent' where students had problems both with the node and its collocate thus leading to combinations like 'win a competitor', win the enemy', 'win the opponent' and the others, which can be seen in Table 7.

Test results were analysed by SPSS which was used for statistical data analysis. The aim was to show which task was the most difficult for primary school students. The results of SPSS analysis can be seen in Table 8.

Table 8. SPSS analysis of differences between exercises.

\begin{tabular}{|c|c|c|c|c|c|c|}
\hline $\begin{array}{c}\text { Difference } \\
\text { between exercises }\end{array}$ & $\begin{array}{c}\mathrm{M} \\
\text { difference }\end{array}$ & stdv & $\begin{array}{c}\text { Std. Error } \\
\text { Mean }\end{array}$ & $\mathrm{t}$ & $\mathrm{df}$ & $\mathrm{p}$ \\
\hline I and II & 0.65 & 0.98 & 0.154 & 4.215 & 39 & .000 \\
\hline I and III & 2.43 & 1.06 & 0.168 & 14.476 & 39 & .000 \\
\hline I and IV & 1.86 & 1.42 & 0.224 & 8.365 & 39 & .000 \\
\hline
\end{tabular}

As can be seen from Table 8, the difference between the receptive, productivereceptive and productive level was examined by a paired samples t-test. The difference between the score obtained in the first group of exercises - multiple choice and the score in the second group of exercises -gap-fill is statistically significant $(\mathrm{t}=4.215, \mathrm{p}<0.05)$.

The difference between Exercise I multiple choice (receptive level) and the third group -Translation into Croatian is also statistically significant $\mathrm{p}<0.05$.

The difference in score between the Exercise I -Multiple choice (receptive level) and the score in the fourth group of exercises - translation into English is also statistically significant because $p$ is $<0.05$ ). It can be seen that the receptive level is much easier for students than the productive level.

\subsection{Secondary school results}

The principle in secondary school testing and analysing the results was the same. Table 9 shows the results of multiple choice exercise.

As with primary school students, this was the easiest exercise with only a few mistakes. The most difficult collocation was 'take somebody's word' with the highest number of incorrect answers and the easiest were 'change her mind' and 'take risk' where in each case only one student from a bigger city made a mistake. 
Table 9. The most frequent errors of multiple choice exercise

\begin{tabular}{|l|l|l|}
\hline \multirow{2}{*}{ Target collocation } & \multicolumn{2}{|c|}{ The most frequent errors } \\
\cline { 2 - 3 } & Bigger city students & Smaller city students \\
\hline Broaden horizons & Lengthen horizons & Straighten horizons \\
\hline Take sb's word & Have sb's word & Believe sb's word \\
\hline Change her mind & Make her mind & ---------- \\
\hline Make decision & ------ & Take decision \\
\hline Take the risk & Have the risk & --------- \\
\hline
\end{tabular}

The situation was different in the second exercise, gap-fill, as it can be seen in Table 10.

Table 10. The most frequent errors of gap-fill exercise.

\begin{tabular}{|c|c|c|}
\hline \multirow[t]{2}{*}{ Target collocation } & \multicolumn{2}{|c|}{ The most frequent errors } \\
\hline & Bigger city students & Smaller city students \\
\hline Make the reservation & $\begin{array}{l}\text { Book the reservation } \\
\text { Confirm the reservation } \\
\text { Take the reservation } \\
\text { Do the reservation } \\
\text { Pay the reservation }\end{array}$ & $\begin{array}{l}\text { Take the reservation } \\
\text { Hook the reservation } \\
\text { Confirm the reservation }\end{array}$ \\
\hline Miss the train & Late to the train & Took the train \\
\hline Have an accident & $\begin{array}{l}\text { Make an accident } \\
\text { Cause an accident }\end{array}$ & $\begin{array}{l}\text { Make an accident } \\
\text { Cause an accident }\end{array}$ \\
\hline Cash a cheque & $\begin{array}{l}\text { Write a cheque } \\
\text { Get a cheque } \\
\text { Bank a cheque } \\
\text { Make a cheque } \\
\text { Change a cheque } \\
\text { Have a cheque } \\
\text { Do a cheque }\end{array}$ & $\begin{array}{l}\text { Write a cheque } \\
\text { Take a cheque } \\
\text { Deposit a cheque } \\
\text { Put a cheque } \\
\text { Change a cheque }\end{array}$ \\
\hline Express the opinion & $\begin{array}{l}\text { Have an opinion } \\
\text { Show the opinion } \\
\text { State the opinion } \\
\text { Give the opinion } \\
\text { Say the opinion } \\
\text { Put the opinion }\end{array}$ & $\begin{array}{l}\text { Tell the opinion } \\
\text { State the opinion } \\
\text { Say the opinion } \\
\text { Give the opinion } \\
\text { Add the opinion } \\
\text { Have an opinion } \\
\text { Change the opinion }\end{array}$ \\
\hline
\end{tabular}


As can be seen from Table 10, students had more problems with this type of exercise where the node was provided and they had to give the collocate, a verb. The easiest collocation with very few wrong answers was 'miss the train' where students who made a mistake did not understand that the verb was missing leading to incorrect combinations. Another difficult collocation was 'cash a cheque' which could also be the result of the fact that today there are no longer cheques and they could be too young to remember them, although the collocation appears in their textbooks. In the bigger city school there was not a single correct answer about this collocation. 'Make the reservation' also caused a lot of problems and students came up with interesting results like e.g. 'confirm the reservation' which could be semantically acceptable. 'Hook the reservation' is probably misspelled version of 'book the reservation'.

As with primary school children, translations were the most difficult for secondary school children, too. Table 11 shows the most common errors in translations from English into Croatian.

Table 11. The most frequent errors of translations from English into Croatian.

\begin{tabular}{|l|l|l|}
\hline \multicolumn{1}{|c|}{ Target collocation } & \multicolumn{2}{c|}{ The most frequent errors } \\
\cline { 2 - 3 } & Bigger city students & Smaller city students \\
\hline $\begin{array}{l}\text { Pogriješiti } \\
\text { (Make a mistake) }\end{array}$ & \multicolumn{1}{|c|}{----------- } & -------------- \\
\hline $\begin{array}{l}\text { Propustiti priliku/šansu } \\
\text { (Miss an opportunity) }\end{array}$ & $\begin{array}{l}\text { Izgubio je priliku } \\
\text { Prokockao je šansu }\end{array}$ & ---------------- \\
\hline $\begin{array}{l}\text { Biti ponosan } \\
\text { (Feel proud) }\end{array}$ & Osjećati se ponosno & Osjećati se ponosno \\
\hline $\begin{array}{l}\text { Požaliti se } \\
\text { (Make a complaint) }\end{array}$ & $\begin{array}{l}\text { Uložiti žalbu } \\
\text { Napraviti pritužbu } \\
\text { Izreći primjedbu } \\
\text { Imati žalbu } \\
\text { Podići žalbu }\end{array}$ & $\begin{array}{l}\text { Napraviti prigovor } \\
\text { Podnijeti žalbu } \\
\text { Napraviti žalbu } \\
\text { Dati kompliment } \\
\text { Uložiti tužbu }\end{array}$ \\
\hline $\begin{array}{l}\text { Prijaviti se za posao } \\
\text { (Apply for a job) }\end{array}$ & \multicolumn{2}{|c|}{$\begin{array}{l}\text { Prihvaćen za posao } \\
\text { Dobio posao } \\
\text { Zatražio posao }\end{array}$} \\
\hline
\end{tabular}

As can be seen in Table 11, the easiest collocation was 'make a mistake' which all students translated correctly. The collocation 'miss an opportunity' was easy for smaller city students while two bigger city students made a mistake in translating it. Two collocations had very similar results and these were 'feel proud' which was translated quite literally by some students as osjećati se ponosno and 'make a complaint' where some students did not know the meaning of the node resulting in collocational errors. 'Apply for a job' was easy for bigger city students but a few 
smaller city students made a mistake in the first part of a collocation, i.e. a collocate.

Table 12 shows the errors in the last exercise, translation from Croatian to English.

Table 12. The most frequent errors of translations from Croatian to English.

\begin{tabular}{|l|l|l|}
\hline \multirow{2}{*}{ Target collocation } & \multicolumn{2}{|c|}{ The most frequent errors } \\
\cline { 2 - 3 } & Bigger city students & Smaller city students \\
\hline Have/take a shower & $\begin{array}{l}\text { Take showers } \\
\text { Get shower } \\
\text { Wash } \\
\text { Shower }\end{array}$ & Shower \\
\hline $\begin{array}{l}\text { Make/give/leave a good } \\
\text { impression }\end{array}$ & $\begin{array}{l}\text { Put a god impression } \\
\text { Make a good attitude }\end{array}$ & $\begin{array}{l}\text { Put a good impression } \\
\text { Take a good impression }\end{array}$ \\
\hline Take part & $\begin{array}{l}\text { Participate } \\
\text { Attend } \\
\text { Win }\end{array}$ & $\begin{array}{l}\text { Participate } \\
\text { Take the advice }\end{array}$ \\
\hline Take/accept the advice & $\begin{array}{l}\text { Follow the advice } \\
\text { Except the advice } \\
\text { Listen the advice }\end{array}$ \\
\hline ment & $\begin{array}{l}\text { Make a deal } \\
\text { Agree } \\
\text { Settle an agreement }\end{array}$ & $\begin{array}{l}\text { Have agree } \\
\text { Set an agreement } \\
\text { Make a deal } \\
\text { Have a deal }\end{array}$ \\
\hline
\end{tabular}

The easiest collocation was 'take/have shower' although some students also used 'shower' as the verb - the same as primary school students. However, unlike primary school students, secondary school students were aware of both collocations, i.e. 'have shower' and 'take shower'. 'Take advice' also proved to be an easy collocation with only few students making a mistake. 'Make/leave/give good impression' also did not result in many mistakes. 'Reach an agreement' was the most difficult collocation producing various combinations as a result of students not being familiar with either the verb or the noun. Thus, students frequently used 'deal' instead of 'agreement' or they even used a verb instead of the noun ('agree').

Test results were also analysed by SPSS which was used for statistical data analysis. The analysis shows which task was most difficult for secondary school students. The results of SPSS analysis can be seen in Table 13. 
Table 13. SPSS analysis of differences between exercises.

\begin{tabular}{|c|c|c|c|c|c|c|}
\hline $\begin{array}{l}\text { Difference between } \\
\text { exercises }\end{array}$ & M difference & stdv & $\begin{array}{c}\text { Std. } \\
\text { Error } \\
\text { Mean }\end{array}$ & $\mathrm{t}$ & $\mathrm{df}$ & $\mathrm{p}$ \\
\hline I and II & 1.23 & 0.18 & 0,188 & 6.526 & 39 & .000 \\
\hline I and III & -0.10 & 0.16 & 0.155 & - & 39 & .523 \\
\hline I and IV & 0.48 & 0.13 & 0.129 & 3.681 & 39 & .000 \\
\hline
\end{tabular}

The difference between the receptive, productive-receptive and productive level was examined by a paired samples t-test. The difference between the score obtained in the first group of exercises - multiple choice and the score in the second group of exercises - gap-fill is statistically significant $(t=6.526, p<0.05)$.

The difference between Exercise I multiple choice (receptive level) and the third group -Translation into Croatian is not statistically significant.

The difference in score between the Exercise I -Multiple choice (receptive level) and the score in the fourth group of exercises - translation into English is also statistically significant because $\mathrm{p}$ is $<0.05$ ). It can be seen that, similar to primary school students, the secondary school students find the receptive level much easier than the productive level. The results only vary in that for secondary school students there is almost no difference between receptive and receptive-productive level.

\section{Conclusion and further recommendations}

This paper deals with collocational competence of primary and secondary school children. After conducting the analysis of primary and secondary school textbooks, it was shown that the number of exercises dealing with collocations is quite scarce.

The second study, which tested the knowledge of collocations of 40 primary and 40 secondary school children, showed that students still heavily rely on their mother tongue or use approximation, i.e. guess the collocation. However, secondary school students are a little bit better on the receptive-productive level since they made fewer mistakes in translations from English to Croatian than their primary school counterparts. Therefore, the results corroborate the findings of other studies of collocations use (see Table 1).

The results of the study bear important implications for teaching collocations. Taking into consideration the importance of collocations on the one hand and the fact that they are one of the most difficult areas for non-native users on the other, it can be concluded that the approach to teaching collocations should be more sys- 
tematic. Explicit vocabulary teaching should not be practiced. It should be known which types of collocations are likely to cause problems at a certain level, thus indicating teachers to introduce such collocation gradually. This could be achieved not only by relying on exercises in textbooks which proved to be insufficient but also by using additional exercises, word games, introducing new words in conjunction with their collocations, doing more translations from English into Croatian and vice versa. Teaching efforts should also concentrate on eliciting the collocations, e.g. matching the appropriate verbs to nouns, completing parts of collocations. Also, explanations of L1-L2 differences in specific collocations and translation practice of these collocations would be effective.

\section{References}

Benson, Morton, Evelyn Benson, Robert Ilson (1986). The BBI combinatory dictionary of English. Amsterdam: John Benjamins Publishing Company.

Crystal, David (1995) The Cambridge Encyclopedia of Language. Cambridge: Cambridge.

Ebrahimi-Bazzaz, Fatemeh, Arshad Abd Samad, Ismi Arif bin Ismail, Nooreen Noordin (2012). Measuring collocational competence of iranian learners by using C-Test, Iranian EFL Journal 8-6.

Firth, John Rupert (1957). Papers in Linguistics. London: Oxford University Press.

Gitsaki, Christine (1999). Second Language Lexical Acquisition. A study of the Development of Collocational Knowledge. San Francisco: International Scholars Publications.

James, Carl (1998). Errors in Language Learning and Use: Exploring Error Analysis. Harlow: Pearson.

Koya, Taeko (2005). The acquisition of basic collocations by Japanese learners of English. Unpublished doctoral dissertation, Waseda University, Japan. Available on-line at http://dspace.wul.waseda.ac.jp/dspace/bitstream/2065/5285/3/Honbun-4160.pdf

Laufer, Batia, Tina Waldman (2011). Verb-noun collocations in second-language writing: A corpus analysis of learners. English Language Learning 61.2: 647-672.

Lewis, Michael, ed. (2000). Teaching Collocation: Further Developments in the Lexical Approach. London: Language Teaching Publications.

McCarthy, Michael (1995). Vocabulary. Oxford: Oxford University Press.

Miščin, Evelina (2012). Glagolske kolokacije u engleskome jeziku medicinske struke. Unpublished Doctoral Thesis. University of Osijek.

Miščin, Evelina (2015). Testing collocational competence of business English students. Global Scholastic Research journal 1.7: 6-19.

Nattinger, James R., Jeanette DeCarrico S. (1992). Lexical Phrases and Language Teaching, Oxford: Oxford University Press

Pavičić Takač, Višnja, Evelina Miščin (2013). Exploring the collocational competence of nonnative users of medical English. JAHR 7.4: 235-257.

Woolard, George (2000). Collocation-encouraging learner independence. Lewis, Michael, ed. Teaching collocation: Further Developments in the Lexical Approach. London: Language Teaching Publication, 28-46. 
Author's address:

postal: Domagojeva 27, 10000 Zagreb, Croatia e-mail: evelinamiscin@yahoo.co.uk

Received September 21, 2015

Accepted for publication November 20, 2015 